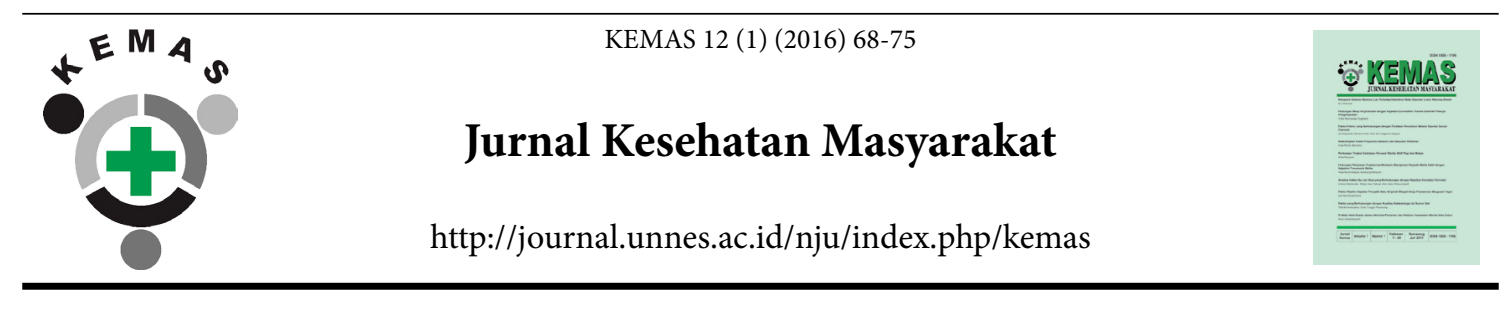

\title{
THE DETERMINANTS OF HUSBAND BEHAVIOR IN THE CARE OF PREGNANT WOMEN
}

Elviera Gamelia $^{1 \bowtie}$, Siti Masfiah ${ }^{1}$, Indah Purnama Sari ${ }^{2}$

${ }^{1}$ Jurusan Public Health Department, Faculty of Health Sciences, Unsoed

${ }^{2}$ Public HealthFaculty, Sriwijaya University, Palembang

\section{Article Info}

Article History:

Submited April 2015

Accepted June 2016

Published July 2016

Keywords:

Behavior; Role of

husband; Pregnancy Care

DOI

http://dx.doi.org/10.15294/

kemas.v12i1.3465

\begin{abstract}
Maternal Mortality Rate (MMR) and Infant Mortality Rate (IMR) in Banyumas District are still below The Minimum Service Standard (MSS), especially in Puskesmas (Public Health Center) I Ajibarang. The strategies for reducing maternal mortality are conducted by increasing mother's health status during pregnancy. This study aims at determining the factors of husband's role in women's prenatal care. Cross-sectional method was used. The populations were all of the pregnant women in Puskesmas I Ajibarang. Proportional random sampling was applied to select 90 pregnant women. Logistic regression was used to determine factors. Theory of planned behavior was used to explore the determinants of husband's role. The results show that the level of education, family income, the knowledge, the attitude, and subjective norm are not related to husband's role in mother prenatal care. However, husband's behavior control $(\mathrm{p}=0.045)$ and intention $(\mathrm{p}=0.000)$ have relation with husband's role in women prenatal care. Variable of intention is the most dominant variable related to husband's role in women's prenatal care.
\end{abstract}

\section{Introducton}

National Health Development Strategy to foster health level is by implementing the National Development based on health knowledge. The program aims to create clean and healthy living behavior among people, to provide equal and qualified health service and to realize high level of health care. There are several indicators used to measure the health status of mothers in a region, one of which is by mother mortality rate (MMR). MMR is one indicator that is closely related to the quality and accessibility of health care facilities. Based on the Indonesian Demographic and Health Survey (IDHS) in 2012, MMR (related to pregnancy, childbirth, and postpartum) is amounted to 359 per 100,000 live births. This figure is still enough as compared to neighboring ASEAN States. The maternal mortality rate (MMR) in Central Java in 2012 reached 116.34 per 100,000 live births. As many as $57.93 \%$ of the deaths occurred during postpartum, $24.74 \%$ occurred at the time of pregnancy and $17.33 \%$ occured at the time of delivery (Dinas Kesehatan Provinsi Jawa Timur). The data from the District Health Office of Banyumas in 2012, Banyumas Regency was ranked 6 out of 35 regencies in Central Java with MMR at 112 per 100,000 live births and 32 MMRs. The data is declined as compared to the data in 2011, MMR is in the range of 129.35 per 100,000 live births, but the rate is still higher than the target of MMR in Central Java province that is 60 per 100,000 live births (Dinas Kesehatan Provinsi Jawa Tengah, 2012).

The government has made various strategic efforts in decreasing MMR to save mother and to ensure all women in getting the proper cares so that they can be safe and healthy during pregnancy and childbirth. This Safe Motherhood Initiative program is followed up by launching Gerakan Sayang Ibu (GSI) and Suami Siaga (Siap, Antar, Jaga). The programs involve various government sectors and the husband's role in prenatal care to pregnant 
women. One indicator of pregnancy is prenatal care that includes $\mathrm{K} 1$ and $\mathrm{K} 4$ coverage. The coverage remains low in Puskesmas I Ajibarang and is still below minimum service standards (MSS). The coverage of $\mathrm{K} 1$ in Puskesmas I Ajibarang of $97.87 \%$ is still below the MSS which should be $100 \%$ while the K4 coverage is $92.05 \%$ which is still below the $95 \%$ MSS (Dinas Kesehatan Provinsi Jawa Tengah, 2012).

Prenatal care is associated with behaviors that are influenced by predisposing factors, enabling factors and reinforcing factors. One of the factors dealing with the behavior of prenatal care by pregnant women is a reinforcing factor, namely the role of husband. Gamelia, et al state that the husband's role is related to the behavior of prenatal care of pregnant women in Puskesmas I Ajibarang and behavior of the husband in the care of pregnant women which are lacking in terms of preparing good nutrition, delivering obstetric, providing information about pregnancy, advocating exercises and accompanying pregnant women to exercise and less awareness of providing support for prenatal care (Gamelia, 2013). In addition, the research from Olayemi (2009) states that educational background has influence in accompanying the wives (pregnant women) for prenatal care $(p$-value $=0.0001 \mathrm{OR}=1.57)$. The result of previous research on factors that affect the behavior of husband in prenatal care focuses more on the theory of knowledge and attitudes. This study uses a differently theoretical approach which is through Planned of Behavior Theory.

This study aims to determine the determinants of husband's behaviors in pregnant women care in area of Puskesmas Ajibarang I Banyumas. Therefore, the research question is "how big is the influence of education, income, knowledge, attitudes, subjective norms, behavioral control and intention of husband's behaviors in pregnant women care in Puskesmas I Ajibarang Banyumas?"

\section{Method}

This study is a survey research. This research used cross sectional approach. Variables observed were independent variables consisting of education, income, knowledge, attitudes, subjective norms, behavioral control and intention of husbands while the dependent variable is the behavior of the husband in pregnant women care. The target population in this study was all mothers residing in Puskesmas I Ajibarang. And the study population was all pregnant women in Puskesmas I Ajibarang. The sample was the husband of the pregnant women majority in Puskesmas I Ajibarang who resided in the village with $\mathrm{K} 1$ and $\mathrm{K} 4$ coverage below the MSS, namely in Ajibarang Wetan village, Karang Bawang village, Kracak Village and Pandansari Village. Determination of the amount minimum sample used the below formula with $\alpha$ : 0.05 and strength test: $80 \%$ (Supriyadi, 2014)

$n=\frac{\left\{Z_{1-\alpha / 2} \sqrt{2 \bar{P}(1-\bar{P})}+Z_{1-\beta} \sqrt{P_{1}\left(1-P_{1}\right)+P_{2}\left(1-P_{2}\right)}\right\}^{2}}{\left(P_{1}-P_{2}\right)^{2}}$

Minimum sample size was calculated by using some of the results of research related to the variables in this study.

The sample calculation resulted minimum sample size of 90 people who were divided proportionally in four villages namely Ajibarang Wetan with 22 pregnant women, Karang Bawang with 24 pregnant women, Kracak with 29 pregnant women and Pandansari with 15 pregnant women. Simple random sampling was used random table to determine the selected sample: the husband of pregnant women. The criteria for inclusion were the husbands who had pregnant wives, the wives who had checked the pregnancy and husbands who were willing to become respondents. The exclusion criteria were the pregnant women who had with pregnancy diseases (hypertension,

Table 1. Calculation of the Minimal Sample

\begin{tabular}{lllcccc}
\hline No. & Variables & \multicolumn{1}{c}{ Research (year) } & \multicolumn{1}{c}{$\mathrm{P}_{1}$} & \multicolumn{1}{c}{$\mathrm{P}_{2}$} & \multicolumn{1}{c}{$\begin{array}{c}\text { Number of } \\
\text { minimal sample }\end{array}$} & Total \\
\hline 1. & Education & Olayemi et al (2009) & $18,52 \%$ & $45,98 \%$ & 45 & 90 \\
2. & Knowledge & Kura et al (2013) & $68,6 \%$ & $38,6 \%$ & 43 & 86 \\
\hline
\end{tabular}

Source : Primary Data 
pre-eclampsia, and diabetes mellitus), the husbands who were outside the city and had been visited by enumerators more than twice when the husbands were not in place.

The data collection was conducted using questionnaires (structured questions) with the first interview method being tested prior to the implementation to meet the validity and reliability standards. Analysis of the data used univariate analysis with descriptive statistics that aimed to explain and describe the characteristics of each variable. The bivariate analysis was conducted to determine the relationship between independent variables and the dependent variable using chi square test which showed relationship if the p-value was $\leq 0,05$. Multivariate analysis was used to determine the relationship of more than one independent variables and the dependent variables and to determine the most dominant variables using multiple logistic regressions.

\section{Results and Discussion}

From the study of the pregnant women husbands in the working area of Puskesmas Ajibarang I, the characteristics of husband from pregnant women are as follows in Table 2.

From Table 2, it can be seen that the majority of husbands are $\geq 33$-year-old husband (51.1\%) with a job (36.7\%) as a laborer, $41.1 \%$ of respondents with one time pregnancy history, $68.9 \%$ of respondents use motorcycles as transportation to health services and $(57.8 \%)$ of respondents require 5-10 minutes travel time to get to the health service.

Behavior of the husband in the care of pregnant women being measured is the action that the husbands do in the treatment of pregnant women including behavioral in giving information (books), providing the cost

Table 2. Characteristics of Pregnant Women husbands in Puskesmas I Ajibarang in 2014

\begin{tabular}{|c|c|c|c|c|}
\hline No & Characteristics & Category & $\mathrm{f}$ (people) & Percentage (\%) \\
\hline \multirow[t]{2}{*}{1} & \multirow[t]{2}{*}{ Husband age } & $<33$ year old & 44 & 48,9 \\
\hline & & $\geq 33$ year old & 46 & 51,1 \\
\hline \multirow[t]{6}{*}{2} & \multirow[t]{6}{*}{ Husband Jobs } & Self-employed & 21 & 23,3 \\
\hline & & Farmer & 4 & 4,4 \\
\hline & & Trader & 15 & 16,7 \\
\hline & & Private employee & 13 & 14,5 \\
\hline & & Laborer & 33 & 36,7 \\
\hline & & Others & 4 & 4,4 \\
\hline \multirow[t]{5}{*}{3} & \multirow[t]{5}{*}{ Birth History } & Never & 31 & 34,4 \\
\hline & & 1 time & 37 & 41,1 \\
\hline & & 2 times & 16 & 17,8 \\
\hline & & 3 times & 4 & 4,5 \\
\hline & & 4 times & 2 & 2,2 \\
\hline \multirow[t]{4}{*}{4} & \multirow{4}{*}{$\begin{array}{l}\text { Transportation to the } \\
\text { health service }\end{array}$} & On foot & 23 & 25,6 \\
\hline & & Motorcycle & 62 & 68,9 \\
\hline & & Car & 3 & 3,3 \\
\hline & & Public transportation & 2 & 2,2 \\
\hline \multirow[t]{4}{*}{5} & \multirow{4}{*}{$\begin{array}{l}\text { Traveling time to the } \\
\text { health service }\end{array}$} & $<5$ minutes & 15 & 16,7 \\
\hline & & 5-10 minutes & 52 & 57,8 \\
\hline & & $10-30$ minutes & 18 & 20,0 \\
\hline & & $>30$ minutes & 5 & 5,5 \\
\hline
\end{tabular}

Source: primary data 
of prenatal care, behavioral of maternity care (personal hygiene of wife), listening to the wives, giving proper nutrient management and physical activity. The results that are obtained are presented in the following data in Table 3.

Based on Table 3, it is known that respondents with basic education (SD / MI and SD / MTs) are 36.6\% higher than those of respondents with secondary education (SLTA / MA) and more than $50.0 \%$ of respondents who havehighereducation (university). Respondents with income $<1$ million are $2.2 \%$ higher than those of respondents who earn $\geq 1$ million. Respondents who have good knowledge are $15.6 \%$ higher than those of respondents who have less knowledge. Respondents who have a lack of support are $15.6 \%$ higher than those of respondents who have supportive attitude towards maternity care. Respondents with both subjective norms are $6.6 \%$ higher than those of respondents with poor subjective norm in the care of pregnant women. Respondents with good behavior control are $20.0 \%$ bigger than those of respondents with poor control behavior in the care of pregnant women. Respondents with the intention are 11.2\% higher than those of respondents with the poor intention in the treatment of pregnant women. Respondents who have good behavior in the care of pregnant women are $22.2 \%$ higher than those of respondents who have poor behavior in the care of pregnant women.

Table 3. Univariate Analysis of husband Behavioral Determinants in Pregnancy Care in Puskesmas I Ajibarang 2014

\begin{tabular}{|c|c|c|c|c|}
\hline No & Variables & Category & $\mathrm{f}$ (people) & $\begin{array}{l}\text { Percentage } \\
(\%)\end{array}$ \\
\hline \multirow[t]{3}{*}{1} & \multirow[t]{3}{*}{ Education } & Primary (SD/MI and SLTP/MTs) & 56 & 62,2 \\
\hline & & Secondary (SLTA/MA) & 23 & 25,6 \\
\hline & & Higher (University) & 11 & 12,2 \\
\hline \multirow[t]{2}{*}{2} & \multirow[t]{2}{*}{ Income } & $<1$ million & 46 & 51,1 \\
\hline & & $\geq 1$ million & 44 & 48,9 \\
\hline \multirow[t]{2}{*}{3} & \multirow[t]{2}{*}{ Knowledge } & less & 38 & 42,2 \\
\hline & & good & 52 & 57,8 \\
\hline \multirow[t]{2}{*}{4} & \multirow[t]{2}{*}{ Attitude } & lack of support & 52 & 57,8 \\
\hline & & support & 38 & 42,2 \\
\hline \multirow[t]{2}{*}{5} & \multirow[t]{2}{*}{ Subjective Norm } & poor & 42 & 46,7 \\
\hline & & good & 48 & 53,3 \\
\hline \multirow[t]{2}{*}{6} & \multirow[t]{2}{*}{ Behavior Control } & poor & 36 & 40,0 \\
\hline & & good & 54 & 60,0 \\
\hline \multirow[t]{2}{*}{7} & \multirow[t]{2}{*}{ Intention } & poor & 40 & 44,4 \\
\hline & & good & 50 & 55,6 \\
\hline \multirow[t]{2}{*}{8} & \multirow[t]{2}{*}{ Husband Behavior } & poor & 35 & 38,9 \\
\hline & & good & 55 & 61,1 \\
\hline
\end{tabular}

Source: primary data

The determinant behaviors of the husband in the care of pregnant women in the working region of Puskesmas I Ajibarang are analyzed one by one using bivariate analysis. The independent variables used are the characteristics of the respondent (including education, income, knowledge, attitudes, subjective norms, behavioral control and intention), while the dependent variable is the behavior of the husband in the care of pregnant women.

The results of chi-square test to look at the relationship of the independent variables with variable of pregnancy care can be seen in 
Table 4.

The result of the study (Table 4) shows that the husband education is not related to the behavior of the husband in the care of pregnant women. The results are consistent with research from Wai (2015) which states that there is no relationship between education husband with husband's involvement the wife to go to the Antenatal/Prenatal (ANC) examination of more than once $(\mathrm{AOR}=1.32,95 \% \mathrm{AOR}=0.76$ to 2.28). The results of subsequent studies show that income is not related to the behavior of the wife's pregnancy care. The result is in contrary with the research from Bhatta in Nepal stating that the husbands who have income above 5001 NPR ( 1 USD = 85 NPR) have a 1.47 times has higher likelihood to accompany the wife (pregnant women) to do ANC than the husbands who have an income of less than 5000 NPR (95\% CI OR $=1.20$ to 1.80 ) (Bhatta, 2013).

Table 4 also shows that knowledge is not related to the behavior of the husband in the care of pregnant women. This study shows that a husband with less knowledge still do good behavior, both at $60.5 \%$, so the knowledge of the husband is not related to the behavior of prenatal care. Among the husbands with less knowledge, there are $50.0 \%$ who provide information about

Table 4. Bivariate Analysis of Husband Behavior Determinants in Pregnancy Care in Puskesmas I Ajibarang 2014

\begin{tabular}{|c|c|c|c|c|c|c|c|}
\hline \multirow{3}{*}{ Variables } & \multicolumn{4}{|c|}{$\begin{array}{l}\text { Husband Behavior in the } \\
\text { pregnant women care }\end{array}$} & \multirow{2}{*}{\multicolumn{2}{|c|}{ Total }} & \multirow{3}{*}{$p$-value } \\
\hline & \multicolumn{2}{|c|}{ Good } & \multicolumn{2}{|c|}{ Poor } & & & \\
\hline & Number & $\%$ & Number & $\%$ & Number & $\%$ & \\
\hline \multicolumn{8}{|l|}{ Husband education } \\
\hline Primary (SD/MI and & & & & & & & \multirow{4}{*}{0,302} \\
\hline & 31 & 55,4 & 25 & 44,6 & 56 & 100,0 & \\
\hline Secondary (SLTA/MA) & 17 & 73,9 & 6 & 26,1 & 23 & 100,0 & \\
\hline Higher (College) & 7 & 63,6 & 4 & 36,4 & 11 & 100,0 & \\
\hline \multicolumn{8}{|l|}{ Income } \\
\hline$<1$ million & 28 & 60,9 & 18 & 39,1 & 46 & 100,0 & \multirow{2}{*}{1,000} \\
\hline$\geq 1$ million & 27 & 61,4 & 17 & 38,6 & 44 & 100,0 & \\
\hline \multicolumn{8}{|l|}{ Knowledge } \\
\hline Less & 23 & 60,5 & 15 & 39,5 & 38 & 100,0 & \multirow{2}{*}{1,000} \\
\hline Good & 32 & 61,5 & 20 & 38,5 & 52 & 100,0 & \\
\hline \multicolumn{8}{|l|}{ Attitude } \\
\hline Lack of support & 28 & 53,8 & 24 & 46,2 & 52 & 100,0 & \multirow{2}{*}{0,151} \\
\hline Support & 27 & 71,1 & 11 & 28,9 & 38 & 100,0 & \\
\hline \multicolumn{8}{|l|}{ Subjective Norm } \\
\hline Poor & 26 & 61,9 & 16 & 38,1 & 42 & 100,0 & \multirow{2}{*}{1,000} \\
\hline Good & 29 & 60,4 & 19 & 39,6 & 48 & 100,0 & \\
\hline \multicolumn{8}{|l|}{ Behavior Control } \\
\hline Poor & 17 & 47,2 & 19 & 52,8 & 36 & 100,0 & \multirow{2}{*}{$0,047^{\star}$} \\
\hline Good & 38 & 70,4 & 16 & 29,6 & 54 & 100,0 & \\
\hline \multicolumn{8}{|l|}{ Intention } \\
\hline Poor & 14 & 35,0 & 26 & 65,0 & 40 & 100,0 & \multirow{2}{*}{$0,000^{\star *}$} \\
\hline Good & 41 & 82,0 & 9 & 18,0 & 50 & 100,0 & \\
\hline
\end{tabular}

Source: primary data 
prenatal care to pregnant women, as many as $76.3 \%$ claim to have set up cost for treatment wife's pregnancy, as many as $68.4 \%$ say that they always take their wife to prenatal health service, as many as $78.9 \%$ say that they always remind their wife to perform routine antenatal care, as many as $65.8 \%$ sat that every day they give more attention for pregnant wife. The results of this study differ from research of Chattopadhyay in India which indicates that a husband who has knowledge of labor in health care facilities have the possibility of 1.589 times higher to accompany his wife to get the delivery in health care facilities than the husband who has no knowledge of deliveries in health-care facilities ( $p$ value- $=0.01)$ (Chattopadhyay, 2011).

Table 4 shows the attitude of husbands to support the wives is as many as 27 husbands who have good behavior in the care of pregnant women $(71.1 \%)$ and as many as 11 husbands (28.9\%) have poor behavior in the care of pregnant women. Attitude is a reaction or response which is still closed from a person to a stimulus or object. Therefore, one's attitude cannot be seen in reality but is realized through the action/behavior. Table 4 also shows that husbands with poor subjective norm as many as 26 husbands who have good behavior in the care of pregnant women $(61.9 \%)$ and as many as 16 husbands (38.1\%) have poor behavior in the care of pregnant women.

This study shows that the husbands with the poor subjective norm who have good behavior are as many as $61.9 \%$ so that the subjective norm owned by a husband is not related to the behavior of maternity care. Among the husband with the poor subjective norm $(85.7 \%)$ claim to have set up cost for treatment wife's pregnancy, and as many as $76.2 \%$ say that they always take their wives for prenatal health service. There are $69.0 \%$ husbands who say that they always remind their wife to go to prenatal regularly and as many as $59.5 \%$ say that every day they give more attention for pregnant wife. These show the support of husband for wife's pregnancy. Adekoya research result and Aluko-Arowolo in Negeria state that there is a relationship between husband supports in the preparation costs of maternal care for ANC examination (Adekoya, 2012). Husband is one of the people closest to wife who plays many roles during pregnancy (prenatal care), childbirth and after birth. Results of research Ramadani (2010) states that the husband's support role in the behavior of exclusive breastfeeding in the mother.

Multivariate analysis is conducted to determine the relationship between independent variable and the dependent variable (the husband's behavior in pregnant women care), to predict the independent variables affect the behavior of the husband in the care of pregnant women and to determine which variables are most closely related to the behavior of the husband in the care of pregnant women. The analysis uses logistic regression of selected variables (variables in bivariate analysis with value Omnibus Tests of Model Coefficients) where the value of $\mathrm{p}<0.25$, namely variables of attitudes, behavioral control and intention. After testing confounding variables, it shows that attitude is not a confounder so that it can be excluded from modeling. The final results of behavior determinants modeling from the husband in pregnant women care can be seen in Table 5 .

Table 5. Multivariate Analysis of Husband Behavioral Determinants in Pregnancy Care in Puskesmas I Ajibarang 2014

\begin{tabular}{lllllll}
\hline $\begin{array}{l}\text { Dependent } \\
\text { Variables }\end{array}$ & $\begin{array}{l}\text { Independent } \\
\text { Variables }\end{array}$ & Category & OR & SE & Value of p & 95\% CI \\
\hline husband & Behavior & Poor & 1,000 & - & - & - \\
$\begin{array}{l}\text { behavior in } \\
\text { the care of }\end{array}$ & control & Good & 2,809 & 0,515 & 0,045 & $1,023-7,710$ \\
$\begin{array}{l}\text { pregnant } \\
\text { women }\end{array}$ & intention & Poor & 1,000 & - & - & - \\
\hline
\end{tabular}

Source : Primary Data 
From table 5, it is known that based on multivariate analysis, the variables which are significantly related to the behavior of the husband in the care of pregnant women in Puskesmas I Ajibarang are behavioral control and intention. The analysis finds that husband with good behavior control has 2,809 times higher chances to behave well in the treatment of pregnant women than the husband with poor behavioral controls (95\% CI: 1.023 to 7.710). The results are consistent with research from Sodikin (2009) which states that there is a significant relationship between husband confidence toward husband behavior as the birth attendant $(\mathrm{p}=<0.001)$. Based on existing data processing result, all husbands (100\%) have good control behavior and behave well in the care of pregnant women who have never been pregnant (expecting their first child). This shows that husbands who expect their first child will provide more intense attention (awareness) so they will not find any trouble in prenatal care (93.5\%). They believe that medical services are quite good in providing services prenatal care (77.4\%), no complaints from their wives about the pregnancy care services obtained from health care facilities (83.9\%), have confidence about good prenatal care for pregnant women $(100 \%)$.

One's intention to behave is a person's tendency to choose to do or not a behavior that is determined by the extent of which the individual has a positive attitude to such behavior, and to what extent he is getting support from other people who influence his life (Dharmmesta, 1998). Multivariate analysis shows that the variable of intention is associated with behavioral treatment of pregnant women with a $\mathrm{p}$-value of 0.000 ( $\mathrm{p}$-value $\leq 0.05)$. The husbands with good intention have 8.703 times higher likelihood to behave well in the care of pregnant women as compared to the husband with poor intention (95\% CI: 3.184 to 23.785 ). Based on the existing data, the husbands who have a desire to seek information about prenatal care for pregnant wife is $62.9 \%$ higher as compared to the husbands who have no desire to seek information about prenatal care for pregnant wife. One source of information about pregnancy care can be obtained through $\mathrm{MCH}$ Book (Maternal and Child Health).
$\mathrm{MCH}$ Handbook is a simple but powerful tool as a means of Information, Education and Communication (IEC) in disseminating important information regarding the Maternal and Child Health $(\mathrm{MCH})$ to the family. $\mathrm{MCH}$ Handbook is potential to improve the knowledge and behavior of family/mother regarding reproductive health and child health because $\mathrm{MCH}$ book contains important information on how to keep your maternal messages and child health that can be read at any time (Sistiarani, 2014).

In addition, the husbands who have the intention to prepare wife's pregnancy care costs since the beginning is $86.6 \%$ higher than the husbands who have no intention to prepare wife's pregnancy care costs from the outset. It is associated with the husband's work. Husband's work is related to the economic levels of pregnant women because economic level affects sleep quality. Low economic level would make pregnant women to be more anxious in facing their pregnancy (Wahyuni, 2013). Therefore, it requires serious role from husbands both psychologically and emotionally during the wife's pregnancy. The results also shows a husband who have good intention to always take their wives for checkups is $91.2 \%$ higher than those of husbands who do not have the intention. The intention of husband is the most related variable to the husband behavior in the care of pregnant women in Puskesmas I Ajibarang Banyumas. In a patriarchal society, husbands influence the decision-making in the family. Similar studies are concerned with the intention which is associated with the behavior of the husband in the care of pregnant women (of reproductive health and IMD) (Story, 2012; Susilowati, 2012).

\section{Conclusion}

Behavioral control and intention are variables that are related to the behavior of the husband in the care of pregnant women. Intention is the most dominant variable related to the behavior of the husband in the care of pregnant women. To be able to bring out the intention of the husband, the wife should participate in motivating her husband so that her husband is able to perform the behavior maternity care. In addition, the 
Health Department and Puskesmas I Ajibarang should further enhance health education and promotion efforts, especially the increase of information about the behavior of prenatal care which is not just intended to pregnant women, but also to their husband. This is necessary because the husband is the main decision maker in the family.

\section{References}

Adekoya, James Adeniyi \& Aluko-Arowolo, Sunday Olusola. 2012. Pregnancy Duartion and Choice of Ante-natal and Delivery Care in Selected Rural and Mixed Urban Areas of Ijebu, South Western Nigeria. Gender \& Behaviour, 10:1.

Bhatta, Dharma Nand. 2013. Involvement of Males in Antenatal Care, Birth Preparedness, Exclusive Breast Feeding and Immunizations for Children in Kathmandu, Nepal. BMC Pregnancy and Childbirth, 13:14.

Chattopadhyay, Aparajita. 2011. Men in Maternal Care Evidence From India. J. Biosoc. Sci., $00: 1-26$.

Dharmmesta, Basu Swastha. 1998. "Theory of Planned Behavoir" Dalam Penelitian Sikap, Niat dan Perilaku Konsumen. Kelola Gadjah Mada University Business Review. Th. VIII, No. 18, h. 85-108:

Dinas Kesehatan Propinsi Jateng. 2012. Laporan Kesehatan Ibu dan Anak. Semarang.

Gamelia, E., Sistiarani, C., Masfiah, S. 2013. Determinan Perilaku Perawatan Kehamilan.
Jurnal Kesehatan Masyarakat Nasional. 8(3): 109-114.

Olayemi, O., et al. 2009. Male Participation in Pregnancy and Delivery in Nigeria: A Survey of Antenatal Attendes. J. Biosoc. Sci. 41: 493503.

Ramadani, M., Hadi, E. N. 2010. Dukungan Suami dalam Pemberian ASI Eksklusif di Wilayah Kerja Puskesmas Air Tawar Kota Padang, Sumatera Barat. Jurnal Kesehatan Masyarakat Nasional. 4(6) : 269-274

Sistiarani, C., Gamelia, E., Hariyadi, B. 2014. Analisis Kualitas Penggunaan Buku Kesehatan Ibu Anak. Jurnal Kemas. 10(1): 14-20.

Sodikin., Ovi, dkk. 2009. Determinan Perilaku Suami yang Mempengaruhi Pilihan Penolong Persalinan Bagi Isteri. Berita Kedokteran Masyarakat. 25(1).

Story et al. 2012. Husbands' Involvement In Delivery Care Utilization In Rural Bangladesh: A Qualitative Study. BMC Pregnancy And Childbirth. 12:28.

Susilowati, Wati., dan Santi E. Purnamasari. 2012. Pemberian Informasi Kesehatan Reproduksi dan Intensi Melakukan Hubungan Seksual Pranikah pada Remaja. Personifikasi. 3(1).

Wahyuni., Ni'mah L. 2013. Manfaat Senam Hamil Untuk Meningkatkan Durasi Tidur Ibu Hamil. Jurnal Kemas, 8(2): 145-152.

Wai, et al. 2015. Are Husbands Involving in Their Spouses' Ulitization of Maternal Care Services?: A Cross Sectional Study in Yangon, Myanmar. PLos ONE. 10:12. 